\title{
First results of multidisciplinary investigations for the hydrogeological conceptual modelling of loess deposits in eastern Croatia
}

\section{Risultati preliminari di uno studio multidisciplinare per la costruzione di un modello idrogeologico concettuale dei depositi di loess della Croazia orientale}

\author{
Marco Pola, Ivica Pavičić, Vedran Rubinić, Ivan Kosović, Lidija Galović, Staša Borović, Lara Wacha, Kosta Urumović
}

Riassunto: Il loess è un deposito continentale di origine eolica. Le acque sotterranee sono la più importante risorsa di acqua potabile nelle zone dove i depositi di loess affiorano. Questo lavoro ha lo scopo di analizzare i depositi di loess della Croazia orientale che costituiscono lo strato a tetto di un acquifero sabbioso sfruttato a scopi irrigui ed idropotabili. Il lavoro si è svolto analizzando e revisionando sia la genesi di questo deposito che i processi post-deposizionali che ne deformano la sua struttura ed integrando le informazioni sedimentologiche con le proprietà idrogeologiche del materiale per proporre un modello idrogeologico concettuale del sistema acquifero studiato. La porosità efficace e la conducibilità idraulica del loess sono state calcolate mediate un approccio analitico partendo dai risultati di analisi granulometriche pubblicate in letteratura. I depositi studiati sono di tipo limoso e si sono formati durante i periodi glaciali del Pleistocene medio-superiore. Questi sedimenti sono stati formati dall'erosione glaciale di rocce affioranti, trasportati dal sistema fluviale del Danubio e successivamente rimobilizzati dal vento e ridepositati formando il loess. Durante i periodi interglaciali, i processi pedogenetici hanno portato alla formazione di un suolo al tetto del deposito e di bioturbazioni e discontinuità sia alla micro- che alla macro-scala. La deposizione di un nuovo strato di loess ha portato alla compattazione e alla consolidazione dello strato precedente. Questo processo ha favorito la riorganizzazione del sedimento alla micro-scala, formando una

Keywords: aquitard, beterogeneity, hydraulic properties, conceptual model, eastern Croatia.

Parole chiave: acquitardo, eterogeneità, proprietà idrodinamiche, modello concettuale, Croazia orientale.

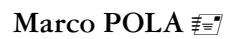 \\ Hrvatski geološki institut - HGI-CGS Sachsova 2, 1000 Zagreb, Croatia \\ Croatian Geological Survey, Zagreb, Croatia \\ mpola@hgi-cgs.hr \\ Ivan KOSOVIĆ, Lidija GALOVIĆ, Staša BOROVIĆ \\ Lara WACHA, Kosta URUMOVIĆ \\ Croatian Geological Survey, Zagreb, Croatia \\ Ivica PAVIČIĆ \\ Faculty of Mining Geology and Oil Engineering, \\ University of Zagreb, Zagreb, Croatia \\ Vedran RUBINIĆ \\ Faculty of Agriculture, University of Zagreb, Zagreb, Croatia
}

Ricevuto/Received: 11 November 2019-Accettato/Accepted: 25 March 2020 Pubblicato online/Published online: 30 March 2020

This is an open access article under the CC BY-NC-ND license:

http://creativecommons.org/licenses/by-nc-nd/4.0/

(C) Associazione Acque Sotterranee 2020 struttura porosa maggiormente sviluppata lungo la verticale, e lo sviluppo di fratture sub-verticali alla macro-scala. La stima delle proprietà idrogeologiche mediante l'approccio analitico utilizzato ha evidenziato la bassa porosità efficace (5-12\%) e la bassa conducibilità idraulica $\left(\sim 10^{-9} \mathrm{~m} / \mathrm{s}\right)$ sia del loess che dei paleosuoli supportando il fatto che i depositi studiati agiscano come un acquitardo. L'infiltrazione delle acque superficiali ed il loro flusso verso l'acquifero sabbioso sottostante è incrementato localmente dalle discontinuità post-deposizionali che rappresentano delle vie di flusso preferenziali all'interno del deposito scarsamente permeabile. Questi risultati evidenziano la necessità di studi idrogeologici più approfonditi dei depositi di loess per chiarire l'impatto dei processi post-deposizionali sulle proprietà idrogeologiche del deposito, per analizzare la loro variazione al variare della scala di indagine e per proporre delle azioni specifiche per la protezione delle risorse idriche sotterranee nelle aree interessate da depositi di loess.

Abstract: Loess is a widespread continental aeolian sediment. Groundwater generally represents the most important source of potable water in loess areas, where loess is the aquitard overlying the aquifer system. This work investigates loess deposits of eastern Croatia that overlie a sandy aquifer exploited for potable and agricultural purposes. The genesis of the deposit and the depositional and post-depositional processes affecting its structure were reviewed in this work and integrated with the estimated hydrogeological properties of the material to propose a preliminary hydrogeological conceptual model of the loess-sand system. The results of published granulometric analyses were used to calculate the effective porosity and the bydraulic conductivity of the material employing an analytical approach. The eastern Croatian loess is a silty deposit originated during Middle-Upper Pleistocene glacial periods. The sediments produced by glacial grinding were transported and deposited by the Danube fluvial system and subsequently remobilised by wind forming the loess. During the interglacial periods, the pedogenesis of the deposit occurred, with bioturbations and discontinuities by living organisms at the micro- and macro-scale. The deposition of a new loess layer compacted and consolidated the previously deposited loess leading to the development of a sub-vertical pore structure and sub-vertical cracks at the micro- and macro-scale, respectively. The calculations from the grain size distributions point to the low effective porosity (5-12\%) and bydraulic conductivity $\left(\sim 10^{-9} \mathrm{~m} / \mathrm{s}\right)$ of both loess and pedocomplexes supporting their aquitard behaviour. The infiltration of surficial waters and their flow toward the underlying sandy aquifer is locally enhanced by the post-depositional discontinuities that constitute preferential flow paths within the loess aquitard. These results highlight the need of detailed hydrogeological investigations in loess deposits to address the impact of post-depositional processes on their hydrogeological behaviour and the upscaling of their hydrogeological properties for proposing specific groundwater protection strategies in loess areas. 


\section{Introduction}

Groundwater management and protection are the main challenges of the $21^{\text {st }}$ century. These tasks require extensive geological and hydrogeological knowledge of the aquifer/ aquitard system for planning adequate groundwater utilisation and protection policies. The aquifer geometry and its hydrogeological properties are important for the sustainable management of the groundwater resource, while protection strategies also demand a detailed characterisation of the aquitard geological and hydrogeological settings.

The groundwater preservation is especially crucial in areas with quantitative and qualitative poor surface waters. These conditions are common in loess regions due to the (semi)arid climate and/or peculiar geological and geomorphological settings ( $\mathrm{Li}$ and Qian 2018). Loess is a predominantly siltsized continental aeolian deposit covering $10 \%$ of the world land area (Muhs et al. 2014; Pye 1987). Most of the loess deposits formed during Quaternary glacial periods draping over the pre-existing morphology as a mantle (e.g., Muhs et al. 2014; Wright 2001). This peculiar genesis defines the current hydrogeological setting of loess regions where loess separates the aquifers, and the potable waters, from the surface waters.

Sedimentological and geochemical investigations are usually conducted to assess the depositional environment of loess and its post-depositional alterations (e.g., Schaetzl et al. 2018; Sprafke and Obreht 2016). Besides the sedimentological features, the depositional and post-depositional processes affect the fabric of the material that is prone to land subsidence, landslides, and collapses (e.g., Derbyshire 2001; Peng et al. 2018).

Despite its importance in aquifer protection, hydrogeological studies on loess are far less frequent than sedimentological and engineering geological investigations. This paper presents the first results of a multidisciplinary research that investigates the hydrogeological behaviour of loess deposits in eastern Croatia. These deposits overlie a multi-layered aquifer exploited for water supply purposes acting as a partial aquitard. In particular, this work reviews the depositional and post-depositional processes affecting loess and elucidates their impact on the physical characteristics of the deposit. This is combined with the hydrogeological characterisation of eastern Croatian loess to propose a preliminary hydrogeological conceptual model of the aquitard-aquifer system.

\section{Geological and hydrogeological settings}

Middle-Upper Pleistocene loess and loess-like deposits and Upper Pleistocene-Holocene alluvial and marshy sediments with a maximum thickness of approximately 100 $m$ extensively crop out in eastern Croatia (Figure 1a). Loess deposits are exposed by tectonic uplifting and river erosion in several sections that were investigated using sedimentological, mineralogical, geochemical, and geochronological approaches (e.g., Galović 2016; Galović et al. 2009; Wacha et al. 2013). Below the outcropping deposits, Middle-Upper Pleistocene sediments up to $200 \mathrm{~m}$ thick occur (Bačani et al. 1999). They consist of interbedded sands, clays, and silts that were deposited in the fluvial and lacustrine environments of the Danube and Drava river systems. The resulting hydrogeological setting is highly heterogeneous varying from a homogeneous aquifer in Baranja region (Duić and Briški 2010; Figure 1b) to a multilayered aquifer in the central and southern parts of the study area (Bačani et al. 1999). This hydrogeological complex is separated from a deeper aquifer hosted in Lower Pleistocene sediments by the electro-log marker Q' (Urumović Sr et al. 1976). The shallower complex is more permeable ( $\mathrm{K}=1.1$ $9.8 \times 10^{-4} \mathrm{~m} / \mathrm{s}$; Bačani et al. 1999; Duič and Briški 2010) and its groundwater mineralisation is relatively lower. The coarse sediments decrease in the deeper unit resulting in lower hydraulic conductivity. The aquifer recharge is provided by the rainfall infiltration, while the rivers mostly drain the groundwaters (Bačani et al. 1999).

\section{Methods}

Sedimentological descriptions of eastern Croatian loess were reviewed and extended by new investigations. The field surveys focused on the identification of discontinuities that could influence the hydrogeological behaviour of the deposit. They were complemented by literature reviews to assess the depositional and post-depositional processes developing the observed discontinuities (e.g., Barta 2011; Smalley et al. 2016) and to evaluate their impact on the loess structure (e.g., Li et al. 2018; Smalley and Marković 2014).

The hydrogeological properties of eastern Croatian loess were determined through an analytical approach and using the results of available granulometric analyses that were conducted on 110 samples collected in three exposed loess sections (Galović et al. 2009).

The hydraulic conductivity was obtained employing the solution of the Kozeny-Carman equation (Urumović and Urumović Sr 2016):

$$
K=\frac{\rho g}{\mu} \frac{n_{e}{ }^{3}}{180\left(1-n_{e}\right)^{2}} D_{g}{ }^{2}
$$

where $\mathrm{K}$ is the hydraulic conductivity $(\mathrm{m} / \mathrm{s}), \mathrm{g}$ is the gravitational acceleration $\left(\mathrm{m} / \mathrm{s}^{2}\right), \rho\left(\mathrm{kg} / \mathrm{m}^{3}\right)$ and $\mu(\mathrm{Pa} \cdot \mathrm{s})$ are the density and viscosity of water, respectively, $n_{e}$ is the effective porosity (-), and $\mathrm{D}_{\mathrm{g}}$ is the geometric mean grain size $(\mathrm{m})$. Considering the water temperature of $10^{\circ} \mathrm{C}$ and that the particle size is generally expressed as $\mathrm{mm}$, equation (1) becomes:

$$
K=0.0417 \frac{n_{e}^{3}}{\left(1-n_{e}\right)^{2}} D_{g}{ }^{2}
$$

$\mathrm{D}_{\mathrm{g}}$ was calculated from the clay, silt, and sand contents of the samples employing a statistical approach (Shirazi et al. 1988). This approach assumes that the particle size curve of each size fraction can be reproduced with a log-normal 


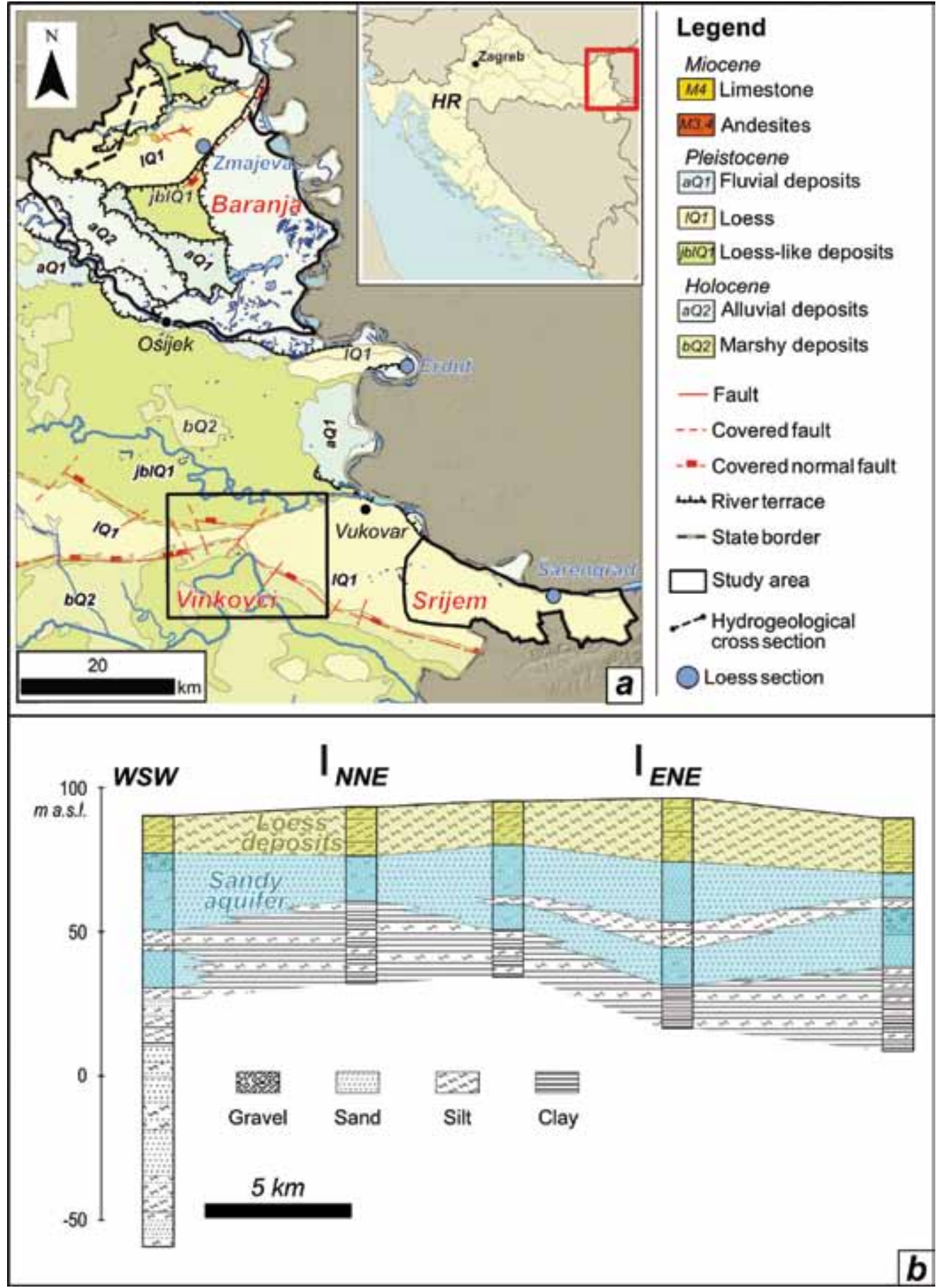

Fig. 1 - (a) Geological map of eastern Croatia (HGI-CGS 2009). Its location is shown in the upper right inset (HR: Croatia). (b) Hydrogeological cross section of the Baranja region (modified from Duić and Briški 2010) showing the predominantly silty loess deposits overlying the sandy aquifer.

Fig. 1 - a) Mappa geologica (HGI-CGS 2009) della parte orientale della Croazia (HR; inquadramento geografico nel riquadro in alto a destra). (b) Sezione idrogeologica della regione Baranja (modificata da Duić and Briški 2010). Si possono osservare i depositi di loess composti prevalentemente da limo a tetto di un acquifero sabbioso.

density function. The content and the grain size limits of a size fraction can be used to calculate its statistical parameters ( $\mathrm{D}_{\mathrm{g}}$ and $\sigma_{\mathrm{g}}$, geometric standard deviation). The parameters are input into the log-normal density function of the size fraction, and then the log-normal density functions of all size fractions are numerically integrated to assess the statistical parameters of the whole sample. These calculations were conducted in the $\mathrm{R}$ environment ( $\mathrm{R}$ Core Team 2018)

The $\mathrm{D}_{\mathrm{g}}$ was calculated for all samples in Galović et al. (2009). The samples were grouped considering their lithological interpretation (Table 1), and the minimum, mean, and maximum $\mathrm{D}_{\mathrm{g}}$ for each group were calculated. The corresponding $\mathrm{n}_{\mathrm{e}}$ values were obtained using an experimental correlation with $\mathrm{D}_{\mathrm{g}}$ spanning over several grain sizes (Urumović and Urumović Sr 2016). Finally, the K was calculated using equation (2). The results were compared with the hydrogeological properties of loess deposits that were determined by laboratory tests on 7 core samples collected during drillings (depths from 22 to $30 \mathrm{~m}$ ) in the eastern part of Srijem region (Figure 1a; Urumović 2013). 


\section{Results and Discussions}

\section{Eastern Croatian loess depositional model}

The eastern Croatian loess (Figure 2a) is part of the loess-paleosol sequences of the Danube basin (Fitzsimmons et al. 2012; Marković et al. 2015, 2016) that are generally considered as "glacial loess" following the depositional model proposed by Wright (2001). The original silty/sandy particles were produced by glacial grinding of the bedrock surfaces in the Alpine region during glacial periods. The Danube fluvial system mobilised and reworked the glacial sediments depositing them in its floodplains. Strong winds entrained and retransported the finest alluvial sediments. The windblown silts redeposited either on land or in lakes and wetlands forming loess or loess-like deposits, respectively (Figure 1a).

During interglacial periods, the pedogenesis of the loess occurred. Many organisms lived in the soil and the underlying original deposit producing different types of discontinuities. The most common are micro- to macro-scale vertical or subvertical root channels (Figure 2c). Loading by newly deposited sediments and the concomitant wetting resulted in the compaction and contraction of the previously deposited loess (Smalley et al. 2016; Smalley and Marković 2014). The rainwater infiltration and the evaporation within the deposits acting preferentially along the vertical direction rearranged and piled up the particles ( $\mathrm{Li}$ et al. 2018). These processes developed a sub-vertically oriented pore structure ( $\mathrm{Li}$ et al. 2018) and polygonal cracks (Figure 2d) at the micro- and macro-scale, respectively. Neotectonic deformations could increase the fracturing of the deposit.

In eastern Croatia, the loess deposits are composed by meterscale loess layers separated by several pedocomplexes (Figure 2a). The loess is a medium to coarse silt with secondary clays and sands (Figure 2b). The paleosols show similar textural characteristics with slightly higher clay content (Figure 2b). In addition, secondary laminated alluvial sediments, which originated from the fluvial reworking of previously deposited loess, are also found. Furthermore, several post-depositional features were recognised at both the micro- and the macroscale (e.g., Galović et al. 2009; Figures 2c and 2d).

\section{Hydrogeological properties of eastern Croatian loess}

The described depositional and post-depositional processes influence the structure of the material and its hydrogeological properties. The compaction decreases the loess void ratio from 1 to 0.6 (e.g., Assadi-Langroudi et al. 2018) resulting in a theoretical total porosity similar to the loess porosities in literature (42-55\%; Li and Qian 2018). Conversely, a low effective porosity is expected due to the fine texture of the material.

The results of the analytical approach used to assess the hydraulic conductivity $(\mathrm{K})$ and the effective porosity $\left(\mathrm{n}_{\mathrm{e}}\right)$ of the different sediments constituting the eastern Croatian loess deposits, as well as their geometric mean grain size $\left(D_{g}\right)$, are reported in Table 1.

The obtained values are comparable with the results of laboratory tests conducted on core samples, and only the minimum $\mathrm{K}$ values of the paleosol and laminated sediments groups are lower than measured values. This difference could be explained by: (i) the higher clay content in paleosol (Figure 2b), (ii) the regional heterogeneity of the investigated deposits, (iii) the minor occurrence of laminated sediments with respect to loess and paleosol diminishing the possibility of an extensive sampling, and (iv) the extension of the granulometric dataset used for the calculation of the hydrogeological properties being larger than the dataset on the hydrogeological testing of core sample.

Tab. 1 - Hydrogeological properties of eastern Croatian loess.

Tab. 1 - Proprietà idrogeologiche dei depositi di loess della Croazia orientale.

Loess sections (original granulometric data in Galović et al. 2009)

\begin{tabular}{|l|c|c|c|c|c|c|c|c|c|}
\cline { 2 - 10 } \multicolumn{1}{c|}{} & \multicolumn{3}{c|}{$\mathrm{D}_{\mathrm{g}}(\mathrm{mm})$} & \multicolumn{3}{c|}{$\mathrm{n}_{\mathrm{e}}(-)$} & \multicolumn{3}{c|}{$\mathrm{K}_{\mathrm{KC}}(\mathrm{m} / \mathrm{s})$} \\
\cline { 2 - 11 } \multicolumn{1}{c|}{} & Min. & Mean & Max. & Min. & Mean & Max. & Min. & Mean & Max. \\
\hline Loess & 0.010 & 0.016 & 0.023 & 0.06 & 0.08 & 0.10 & $1.2 \mathrm{E}-09$ & $5.2 \mathrm{E}-09$ & $2.8 \mathrm{E}-08$ \\
\hline Paleosol & 0.006 & 0.013 & 0.032 & 0.05 & 0.07 & 0.12 & $2.3 \mathrm{E}-10$ & $3.0 \mathrm{E}-09$ & $8.3 \mathrm{E}-08$ \\
\hline $\begin{array}{l}\text { Laminated } \\
\text { sediments }\end{array}$ & 0.008 & 0.016 & 0.024 & 0.06 & 0.08 & 0.10 & $5.5 \mathrm{E}-10$ & $5.2 \mathrm{E}-09$ & $3.0 \mathrm{E}-08$ \\
\hline Modern soil & 0.012 & 0.012 & 0.012 & 0.07 & 0.07 & 0.07 & $2.0 \mathrm{E}-09$ & $2.0 \mathrm{E}-09$ & $2.0 \mathrm{E}-09$ \\
\hline
\end{tabular}

Core samples (Urumović 2013)

\begin{tabular}{|l|c|c|c|c|c|c|c|c|c|}
\cline { 2 - 9 } \multicolumn{1}{c|}{} & \multicolumn{3}{c|}{$\mathrm{D}_{\mathrm{g}}(\mathrm{mm})$} & \multicolumn{3}{c|}{$\mathrm{n}_{\mathrm{e}}(-)$} & \multicolumn{3}{c|}{$\mathrm{K}_{\mathrm{t}}(\mathrm{m} / \mathrm{s})$} \\
\cline { 2 - 10 } \multicolumn{1}{c|}{} & Min. & Mean & Max. & Min. & Mean & Max. & Min. & Mean & Max. \\
\hline Loess & 0.011 & 0.015 & 0.019 & 0.05 & 0.07 & 0.08 & $2.1 \mathrm{E}-09$ & $1.5 \mathrm{E}-09$ & $3.3 \mathrm{E}-08$ \\
\hline
\end{tabular}

Note. $\mathrm{D}_{\mathrm{g}}$ : referential mean grain size; $\mathrm{n}_{\mathrm{e}}$ : effective porosity; K: hydraulic conductivity (subscript KC: Kozeny-Carman equation; t: laboratory tests) 


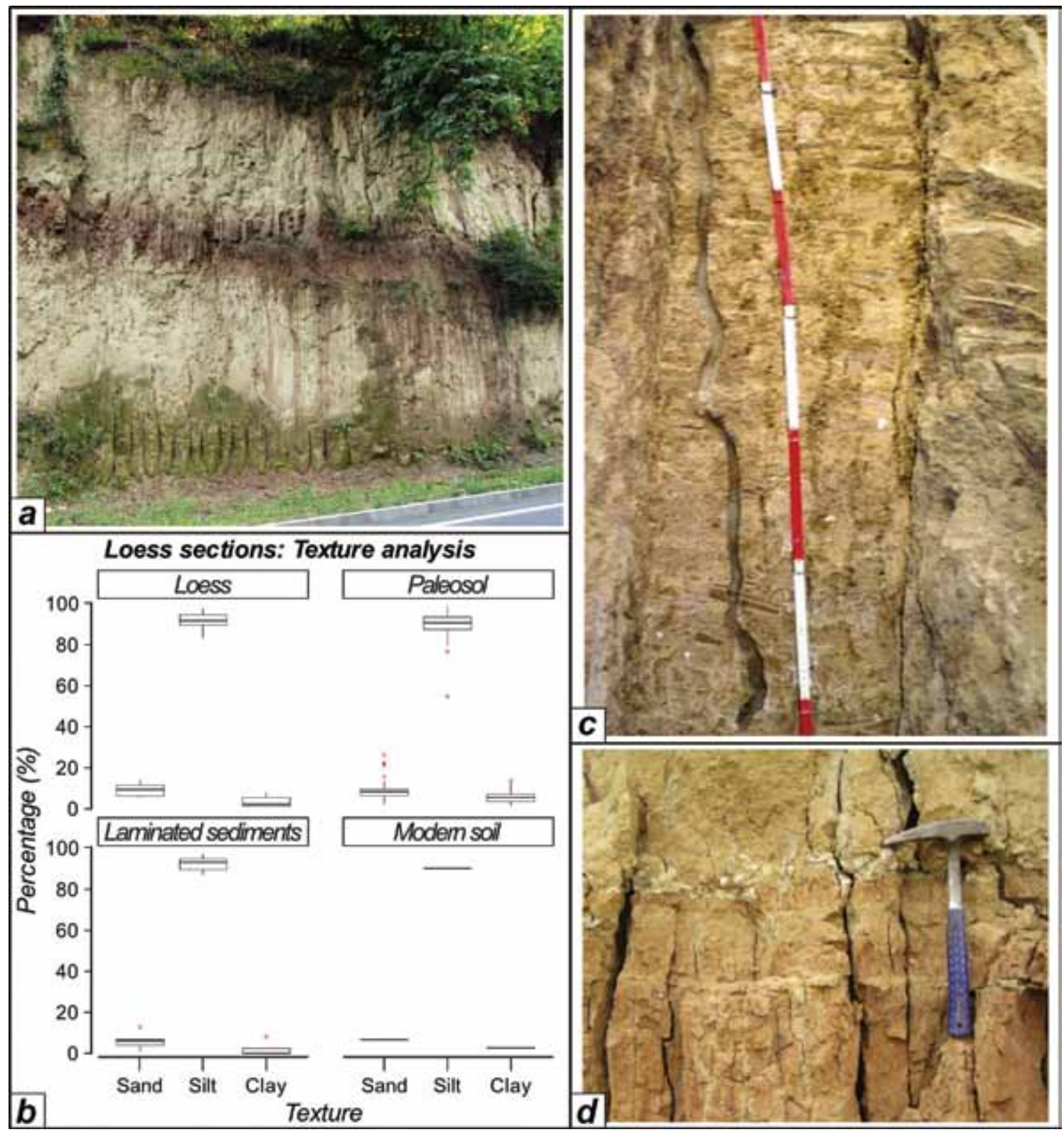

Fig. 2 - (a) Section of loess deposits located to the south of Vukovar. The picture shows two loess layers (light grey) divided by a paleosol (brown). (b) Statistical analysis of loess deposits samples (original data from Galovic et al. 2009). (c-d) Post-depositional discontinuities in the loess deposits (root channel and sub-vertical fissures, respectively, observed in the Zmajevac section).

Fig. 2 - (a) Affioramento a sud di Vukovar. Nell'immagine si notano due strati di loess (grigio chiaro) separati da un paleosuolo (marrone). (b) Analisi statistica di campioni di loess (dati da Galović et al. 2009). (c-d) Discontinuità post-deposizionali in depositi di loess (solco di una radice e fessure sub-verticali osservate nella sezione di Zmajevac)..

\section{Hydrogeological conceptual model of eastern Croatian loess}

Locally infiltrated meteoric waters are the main recharge of eastern Croatian groundwaters (Bačani et al. 1999). They infiltrate through the loess deposits that represent the most extended surficial layer in the study area (Figure 1a). The hydrogeological properties of the deposit (Table 1) show its aquitard behaviour. However, this aquitard is deformed by persistent discontinuities (Figures $2 \mathrm{c}$ and $2 \mathrm{~d}$ ) that represent preferential paths for the water infiltration and flow. The role of these discontinuities as preferential flow paths is corroborated by the deposition of secondary carbonates at their borders (Barta 2011; Galović et al. 2009; Rubinić et al. 2018). Therefore, the infiltration of meteoric waters through loess deposits into the underlying sandy aquifer (Figure 3) could occur at different velocities due to its hydrogeological heterogeneity. This differential flow depends on: (i) the low hydraulic conductivity of the deposit, (ii) the highly permeable post-depositional discontinuities, and (iii) their possible infilling reducing their hydraulic conductivity. 


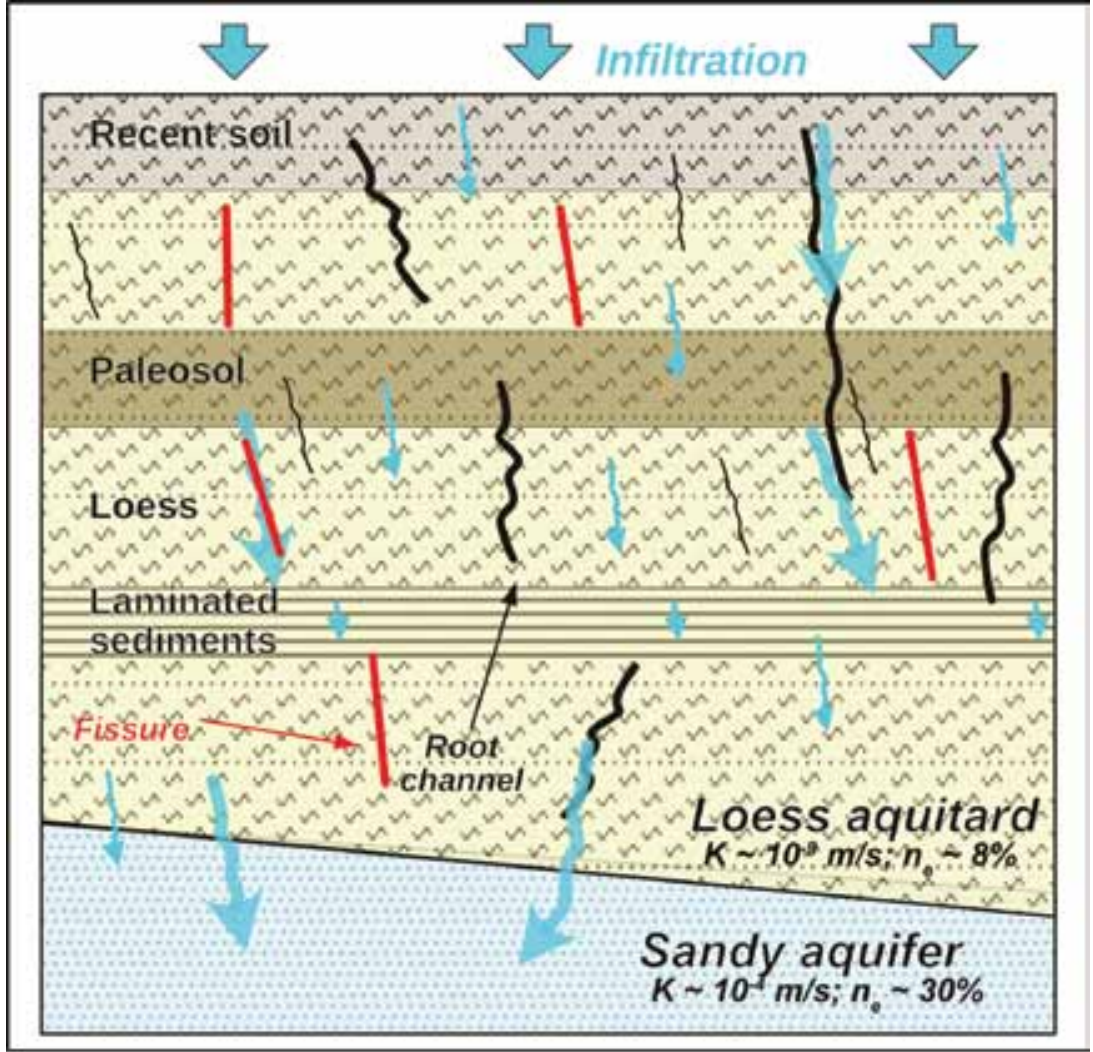

Fig. 3 - Hydrogeological conceptual model of the loesssand system in eastern Croatia. Loess is an aquitard, but post-depositional discontinuities (root channels, fissures) are preferential paths for the water infiltration.

Fig. 3 - Modello concettuale del sistema loess sabbie nella Croazia orientale. Il loess è un aquitardo, ma le discontinuità provate dai processi postdeposizionali (radici, fessure) sono delle vie di flusso preferenziali per l'infiltrazione delle acque.

\section{Conclusion}

This work shows the first results of a recently started research investigating the hydrogeological characteristics of loess deposits in eastern Croatia. The proposed hydrogeological conceptual model suggests that loess is a partial aquitard for the infiltration of meteoric waters into the underlying sandy aquifer. The infiltration could be highly heterogeneous and mostly driven by the post-depositional discontinuities acting as preferential flow paths. This differential infiltration could represent a prominent issue in the protection of the eastern Croatian groundwater resources that are exploited by local users for potable and agricultural purposes. Therefore, the quantification of the hydrogeological properties, the assessment of their dependence on the sedimentological processes, and their upscaling are crucial.

These aspects will be investigated in the next phase of the research. The available regional geological and hydrogeological reconstructions of 3 study areas (Baranja, Srijem, and Vinkovci; Figure 1a) will be updated to establish the horizontal and vertical contacts among recent alluvial sediments, loess deposits, and sandy layers. The reconstructions will be populated with porosity and hydraulic conductivity values obtained from core sample analyses and hydrogeological investigations on new exploration boreholes.

Pedological and geophysical surveys at the scale of the borehole and its surroundings and sedimentological analyses on the cores will be performed. The pedological investigations will elucidate the structure of the modern soil and its role in the infiltration of the surficial waters, while the geophysical surveys will clarify the geometry of the soil-loess-sand system integrating the local geological and hydrogeological reconstructions. Furthermore, the sedimentological analyses will favour the comparison of the drilled loess with other loess deposits in eastern Croatia strengthening the correlation between the local and the regional reconstructions. The assessment of the geological and hydrogeological heterogeneities in the soil-loess-sand system at local and regional scales will unravel the hydrogeological processes developing a strategic groundwater resource for eastern Croatia. These results will be beneficial to propose specific environmental policies and groundwater protection strategies that could be extended in the neighbouring regions being part of the Danube loess (i.e., northern Serbia and southern Hungary) or in other loess areas with similar geological settings where groundwater is a crucial and valuable resource.

\footnotetext{
Acknowledgment: The code used to calculate the geometric mean grain size is available upon request by contacting the corresponding author. The authors would like to thank the editors and the anonymous reviewers for improving our work. This research was funded by the Ministry of Science, Education and Sports of the Republic of Croatia within the project "Basic Hydrogeological Map of the Republic of Croatia 1:100.000" of the Croatian Geological Survey and by the Croatian Science Foundation within the project "Impact of specific surface area on hydrogeological properties of loess deposits and loess-derived soils in eastern Croatia" (ISSAH; UIP-2017-05-9345), grant to K. Urumović.
} 


\section{REFERENCES}

Assadi-Langroudi A, Ng'ambi S, Smalley I (2018) Loess as a collapsible soil: Some basic particle packing aspects. Quaternary International. doi: 10.1016/j.quaint.2016.09.058

Bačani A, Šparica M, Velić J (1999) Quaternary Deposits as the Hydrogeological System of Eastern Slavonia. Geologia Croatica. doi: 10.4154/GC.1999.12

Barta G (2011) Secondary carbonates in loess-paleosoil sequences: a general review. Open Geosciences. doi: 10.2478/s13533-011-0013-7

Derbyshire E (2001) Geological hazards in loess terrain, with particular reference to the loess regions of China. Earth-Science Review. doi: 10.1016/S0012-8252(01)00050-2

Duić Ž, Briški M (2010) Effect of geological structures on the hydrogeological characteristics of quaternary deposits in Baranja. Rudarsko-geološko-naftni zbornik 22: 1-9

Fitzsimmons KE, Marković SB, Hambach U (2012) Pleistocene environmental dynamics recorded in the loess of the middle and lower Danube basin. Quaternary Science. doi: 10.1016/j.quascirev.2012.03.002

Galović L (2016) Sedimentological and mineralogical characteristics of the Pleistocene loess/paleosol sections in the Eastern Croatia. Aeolian Research. doi: 10.1016/j.aeolia.2015.10.007

Galović L, Frechen M, Halamić J, Durn G, Romić M (2009) Loess chronostratigraphy in Eastern Croatia - A luminescence dating approach. Quaternary International. doi: 10.1016/j.quaint.2008.02.004

HGI-CGS (2009) Geological Map of the Republic of Croatia, 1: 300,000. Croatian Geological Survey, Department of Geology, Zagreb.

Li P, Qian H (2018) Water in Loess, in: Meyers R.A. (ed.) Encyclopedia of Sustainability Science and Technology. Springer New York, New York. doi: 10.1007/978-1-4939-2493-6_968-1

Li Y, Zhang T, Zhang Y, Xu Q (2018) Geometrical appearance and spatial arrangement of structural blocks of the Malan loess in NW China: implications for the formation of loess columns. Journal of Asian Earth Sciences. doi: 10.1016/j.jseaes.2018.02.007

Marković SB, Fitzsimmons KE, Sprafke T, Gavrilović D, Smalley IJ, Jović V et al. (2016) The history of Danube loess research. Quaternary International. doi: 10.1016/j.quaint.2015.09.071

Marković SB, Stevens T, Kukla GJ, Hambach U, Fitzsimmons KE, Gibbard P et al. (2015) Danube loess stratigraphy - Towards a panEuropean loess stratigraphic model. Earth-Science Reviews. doi: 10.1016/j.earscirev.2015.06.005

Muhs DR, Cattle SR, Crouvi O, Rousseau DD, Sun J, Zárate MA (2014) Loess Records, in: Knippertz P., Stuut J.B.W. (eds.) Mineral Dust. Springer Netherlands, Dordrecht. doi: 10.1007/978-94-0178978-3_16
Peng J, Qi S, Williams A, Dijkstra TA (2018) Preface to the special issue on "Loess engineering properties and loess geohazards." Engineering Geology. doi: 10.1016/j.enggeo.2017.11.017

Pye K (1987) Aeolian dust and dust deposits. Academic Press, San Diego.

R Core Team (2018) R: A language and environment for statistical computing. R Foundation for Statistical Computing, Vienna, Austria. URL https://www.R-project.org/

Rubinić V, Galović L, Lazarević B, Husnjak S, Durn G (2018) Pseudogleyed loess derivates - The most common soil parent materials in the Pannonian region of Croatia. Quaternary International. doi: 10.1016/j.quaint.2017.06.044

Schaetzl RJ, Bettis EA, Crouvi O, Fitzsimmons KE, Grimley DA, Hambach U, et al. (2018) Approaches and challenges to the study of loess-Introduction to the LoessFest Special Issue. Quaternary Research. doi: 10.1017/qua.2018.15

Shirazi MA, Boersma L, Hart JW (1988) A Unifying Quantitative Analysis of Soil Texture: Improvement of Precision and Extension of Scale. Soil Science Society of America Journal. doi: 10.2136/ sssaj1988.03615995005200010032x

Smalley IJ, Bentley SP, Marković SB (2016) Loess and fragipans: Development of polygonal-crack-network structures in fragipan horizons in loess ground. Quaternary International. doi: 10.1016/j. quaint.2015.01.034

Smalley IJ, Marković SB (2014) Loessification and hydroconsolidation: There is a connection. Catena. doi: 10.1016/j.catena.2013.07.006

Sprafke T, Obreht I (2016) Loess: Rock, sediment or soil - What is missing for its definition? Quaternary International. doi: 10.1016/j. quaint.2015.03.033

Urumović K (2013) Parameter quantification of clastic sediments hydrogeologic properties based on test fields in northern Croatia. Ph.D. thesis, University of Zagreb, Zagreb

Urumović K, Urumović Sr K (2016) The referential grain size and effective porosity in the Kozeny-Carman model. Hydrology and Earth System Sciences. doi: 10.5194/hess-20-1669-2016

Urumović Sr K, Hernitz Z, Šimon J, Velić J (1976) O propusnom mediju kvartarnih te gornjo i srednjo pleistocenskih naslaga sjeverne Hrvatske "About permeable media of Quaternary and Upper and Middle Pleistocene deposits of northern Croatia". Proceedings of IV Yugoslavian symposium on Hydrogeology and Engineering Geology, 1, 395-410

Wacha L, Galović L, Koloszár L, Magyari Á, Chikán G, Marsi I (2013) The chronology of the Šarengrad II loess-palaeosol section (Eastern Croatia). Geologia Croatica. doi: 10.4154/GC.2013.18

Wright JS (2001) Desert loess versus glacial loess: Quartz silt formation, source areas and sediment pathways in the formation of loess deposits. Geomorphology. doi: 10.1016/S0169-555X(00)00060-X 